\title{
Adsorption of metallic ions from aqueous solution on surfactant aggregates: a molecular dynamics study
}

\author{
E. H. Chavez-Martinez, E. Cedillo-Cruz, H. Dominguez iD || \\ Instituto de Investigaciones en Materiales, Universidad Nacional Autónoma de México, UNAM Cd. Mx. 04510,
} México

Received February 19, 2021, in final form May 21, 2021

\begin{abstract}
Metallic ion adsorption on surfactant aggregates were studied with Molecular dynamics simulations. Using ionic salts, such as lead sulfate $\left(\mathrm{PbSO}_{4}\right)$ and aluminum sulfate $\left[\mathrm{Al}_{2}\left(\mathrm{SO}_{4}\right)_{3}\right]$, adsorption of lead and aluminum were investigated at different salt concentrations and different surfactant aggregates (micelles) sizes. The micelles were constructed with spherical shapes composed of sodium dodecyl sulfate (SDS) anionic surfactants. The electrostatic interactions between the positive ions and the negative SDS headgroups promote capture of the metal particles on the aggregate surface. Metal adsorption was analyzed in terms of radial density profiles, partial pair distribution functions and adsorption isotherms. It is showed that SDS micelles adsorb better lead than aluminum ions regardless of the size of the aggregates and salt concentrations.
\end{abstract}

Key words: metal ion adsorption, anionic surfactant, surface adsorption, molecular dynamics, ionic salts

\section{Introduction}

For several years metal pollution in aquatic systems has been the subject of a few investigations due to the severe environmental problems. In particular, heavy toxic metals such as lead, mercury, cadmium and aluminum, among other metallic particles, have been the subject of various studies [1-4] as they are the cause of many health problems in humans. For example, lead can damage the kidneys and liver, while mercury can cause lung damage and kidney impairment. Therefore, removal of those toxic metals from aqueous solutions has become a very important topic not only from a scientific point of view but also for the many industrial applications. Nowadays, different techniques have been used to investigate metallic ion removal, such as chemical precipitation [5], ion-exchange [6], adsorption [7] and membrane precipitation [8]. However, due to their polar properties, surfactant molecules have been used as an alternative to trap metallic ions from aqueous solutions [3, 9,-11]. For instance, porous carbon has been used with anionic and cationic surfactants to increase the removal of metal ions.

An alternative tool to investigate such complex processes are computer simulations. For example, $\mathrm{Hu}$ et al. [12] and Liu et al. [13] studied adsorption and desorption phenomena on solid surfaces. In particular, they investigated adsorption of divalent cations and dodecane desorption from silica surfaces in an aqueous dilution of cetyltrimethylammonium bromide (CTAB). On the other hand, removal studies of organic molecules with surfactants have also been investigated using molecular dynamics simulations [1417].

In a previous work, the removal of lead and mercury ions from aqueous solutions was investigated using an anionic surfactant, sodium dodecyl sulfate (SDS) [18]. For those studies, lead nitrate $\left(\mathrm{Pb}\left(\mathrm{NO}_{3}\right)_{2}\right)$ and mercury chloride $\left(\mathrm{HgCl}_{2}\right)$ salts were used. In that paper it was observed that surfactants improve the retention of metal ions and they work better for mercury than for lead. In the present paper, lead and aluminum ions are studied using the same SDS anionic surfactant, though in this case lead sulfate, $\mathrm{PbSO}_{4}$ and aluminum sulfate, $\mathrm{Al}_{2}\left(\mathrm{SO}_{4}\right)_{3}$, are tested. The use of different salts will allow us to study the effects of salt counterions (sulfate) on the adsorption process.

*Email address: hectordc@unam.mx 


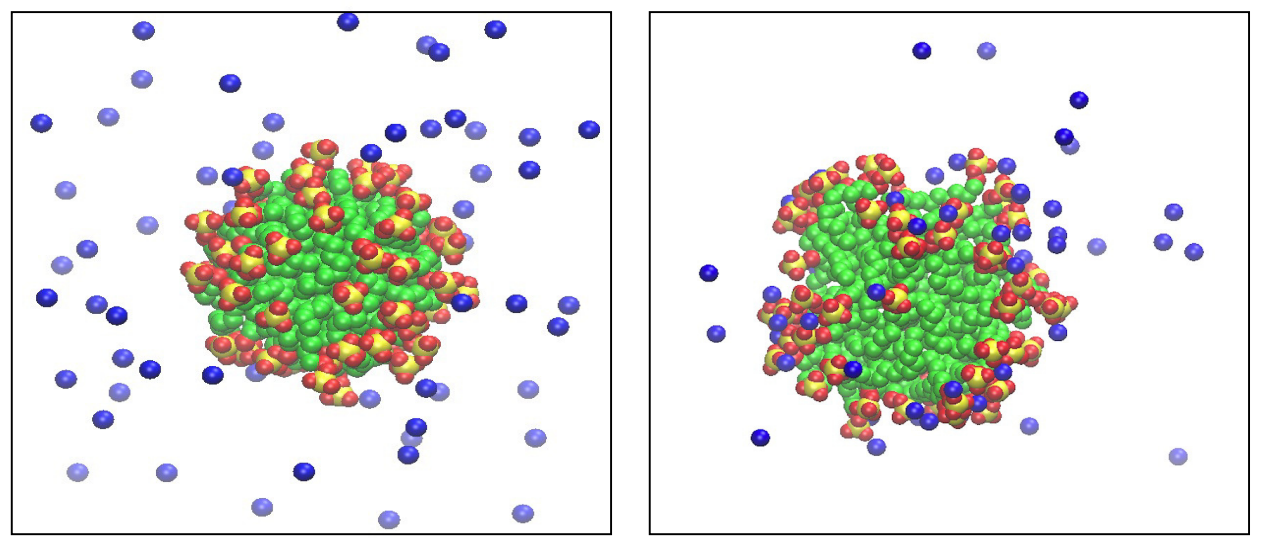

Figure 1. (Colour online) Snapshots of a SDS micelle with $\mathrm{PbSO}_{4}$ salt. Left-hand: Initial configuration. Right-hand: Final configuration. Red and yellow colors represent the SDS headgroups, green represents the SDS tail groups and blue represents the lead ions. For visualization, water and $\mathrm{SO}_{4}$ groups are removed.

\section{Computational model}

Simulations were conducted for two metal ions, lead $(\mathrm{Pb})$ and aluminum (Al) in lead sulfate, $\mathrm{PbSO}_{4}$ and in aluminum sulfate, $\mathrm{Al}_{2}\left(\mathrm{SO}_{4}\right)_{3}$ salts, respectively. Surfactant micelles were prepared with sodium dodecyl sulfate (SDS) molecules using an united atom model. Each SDS molecule consisted of a hydrocarbon chain of 12 united carbon atoms attached to a headgroup, $\mathrm{SO}_{4}^{-}$, i.e., $\mathrm{CH}_{n}$ groups were treated as a single site atom whereas the headgroup atoms were explicitly modelled. The neutrality of the systems was maintained by including a $\mathrm{Na}^{+}$ion for each SDS molecule.

The SDS force field considered intra and intermolecular contributions and the parameters were taken from reference [19], whereas the force field for the metallic ions and for their counterions was taken from [20, 21]. It is worth mentioning that the $\sigma$ Lennard-Jones parameters for the $\mathrm{SO}_{4}$ salt were scaled by a factor of 0.085 to better reproduce the $\mathrm{PbSO}_{4}$ density. For the $\mathrm{SO}_{4}$ ion in the salt, the charges were set to $q_{\mathrm{S}}=0.288$ and $q_{\mathrm{O}}=-0.572$ whereas for the metallic ions, the charges were set to $q_{\mathrm{Pb}}=2.0$ for lead and $q_{\mathrm{Al}}=3.0$ for aluminum. For the aqueous media, water molecules were used with the three-site SPC/E model [22]. The interactions between unlike atoms were obtained using the Lorentz-Berthelot (L-B) combination rules.

Initial configuration started with a single spherical micelle, previously constructed, with SDS molecules and placed in the center of a cubic box. Then, the simulation box was filled with water and the micelle was free to move.

Two systems were prepared with 60 and 90 SDS molecules, respectively for each system, in 11226 water molecules and they were all together equilibrated up to $10 \mathrm{~ns}$. Then, a different number of salt molecules, $\mathrm{PbSO}_{4}$ or $\mathrm{Al}_{2}\left(\mathrm{SO}_{4}\right)_{3}$, were randomly located in the simulation box (using individual ions of $\mathrm{Pb}, \mathrm{Al}$ and $\mathrm{SO}_{4}$ ), i.e., 30, 60 and 90 salt molecules completely dissolved in water, see figure 1 .

All simulations were run in GROMACS-5.1.2 software [23] in the NPT ensemble at temperature $T=298.15 \mathrm{~K}$ and pressure $P=1 \mathrm{bar}$, using the Nosé-Hoover thermostat [24] with a relaxation time of $\tau_{T}=0.1 \mathrm{ps}$, and the Parinello-Rahman barostat [25], with a relation time of $\tau_{p}=2 \mathrm{ps}$, respectively. Periodic boundary conditions were used in all directions and long-range electrostatic interactions were handled using the particle mesh Ewald method [26]. Bond lengths were constrained using the Lincs algorithm [27] and the short range interactions were cut off at $2.0 \mathrm{~nm}$. Then, simulations were carried out up to $50 \mathrm{~ns}$ after $5 \mathrm{~ns}$ of equilibration with a timestep of $d t=0.002 \mathrm{ps}$. Results were analyzed for the last $20 \mathrm{~ns}$ and configuration energy was monitored as function of time to determine when the systems reached equilibrium. 


\section{Results}

\subsection{Micelle and ions structure}

As stated above, initially a spherical micelle was placed in the center of the simulation box. Therefore, to study whether the micelle presents some modification in its shape once salts were added to the system, radii of gyration were investigated. Then, the radii of the micelles were calculated with and without the presence of salt. The radius of the micelle $\left(R_{S}\right)$ is related to the radius of gyration $\left(R_{g}\right)$ as,

$$
R_{S}=\sqrt{\frac{5}{3}} R_{g} .
$$

The eccentricity of the micelle was also calculated as,

$$
e=1-\frac{I_{\text {min }}}{I_{\text {avg }}},
$$

where $I_{\min }$ and $I_{\text {avg }}$ are the moment of inertia with the minimum magnitude and the average of all three moments of inertia, respectively. For a sphere, this value should be zero. The radii of the micelles without salt were $2.06 \mathrm{~nm}$ and $2.36 \mathrm{~nm}$ for the systems with 60 and 90 SDS molecules, respectively, in agreement with previous computational and experimental results [28, 29]. The eccentricities were 0.12 and 0.15 for micelles with 60 and 90 SDS, respectively. When salt was included, those values did not change significantly. In the case of $\mathrm{PbSO}_{4}$ with $60 \mathrm{SDS}$, the radii were between $2.03-2.13 \mathrm{~nm}$, for systems with $30-120$ ion salts. The average eccentricity for those micelles was $\approx 0.13$. For the same system with 90 SDS, the radii of the micelles were between $2.30-2.32 \mathrm{~nm}$, for systems with $30-120$ ion salts. Here, the average eccentricity of the micelles was $\approx 0.12$. In the case of the $\mathrm{Al}_{2}\left(\mathrm{SO}_{4}\right)_{3}$ with $60 \mathrm{SDS}$, the values were similar, for the different ion concentrations the radii were between $2.01-2.10 \mathrm{~nm}$ with an average eccentricity $\approx 0.1$. For the system with $\mathrm{Al}_{2}\left(\mathrm{SO}_{4}\right)_{3}$ and $90 \mathrm{SDS}$, the radii, for the different salt concentrations, were between $2.33-2.38 \mathrm{~nm}$ with an average eccentricity $\approx 0.11$. Then, it was observed that once salt was added in the systems, the size of the micelles did not change and since the eccentricities were small, they remained nearly spherical, see figure 1 .

At the beginning of the simulation the ions were distributed throughout the box, at the end some of them were adsorbed on the micelle and they were deposited close to the SDS headgroups as it is observed in figure 1. In terms of partial pair correlation functions [radial distribution functions, $g_{i j}(r)$ ] it was studied how the metal ions were distributed around the SDS micelles. In figure 2 typical radial distribution functions of the $\mathrm{Al}$ ions [of the $\mathrm{Al}_{2}\left(\mathrm{SO}_{4}\right)_{3}$ ] with the sulfur atoms (of the SDS surfactants) are shown. In the figure, the $g_{\mathrm{S}-\mathrm{Al}}(r)$ of the systems with micelles of 60 SDS and 90 SDS at different $\mathrm{Al}_{2}\left(\mathrm{SO}_{4}\right)_{3}$ salt concentrations are depicted. There is observed a first high peak suggesting a strong interaction between the $\mathrm{Al}$ ions with the sulfur atoms (SDS headgroups). It is also noted that the peak decreases as the salt concentration increases (the number of ions), i.e., there is less probability to find $\mathrm{Al}$ ions close to SDS headgroups at high salt concentrations. Furthermore, higher $g_{\mathrm{S}-\mathrm{Al}}(r)$ peaks are detected in the big micelle (90 SDS) than in the small one at the same salt concentrations, i.e., there is less probability to find Al ions per SDS headgroups in the small micelle. Similar issues were observed for micelles with $\mathrm{PbSO}_{4}$ salt.

\subsection{Metal ion retention}

Retention of the metal ions by the SDS headgroups were studied in terms of radial number density profiles,

$$
\rho(r)=\frac{\mathrm{d} N_{i}(r)}{\mathrm{d} V}
$$

$\mathrm{d} N_{i}(r)$ is the number of ions in a spherical shell of volume $\mathrm{d} V\left(=4 \pi r^{2} \mathrm{~d} r\right)$.

In figures 3 and 4, typical radial density profiles for the SDS headgroups (represented by the sulfur atoms) and $\mathrm{Pb}$ metal ions are shown. At the end of the simulations, the average density profiles of the metal 

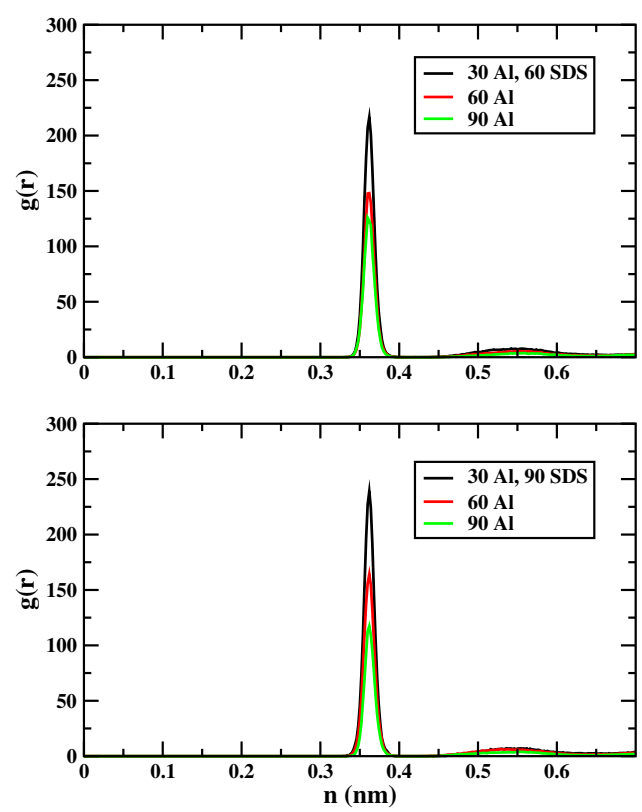

Figure 2. (Colour online) Radial distribution functions, $g_{\mathrm{S}-\mathrm{Al}}(r)$, for the SDS micelle with different number of $\mathrm{Al}_{2}\left(\mathrm{SO}_{4}\right)_{3}$ salt ions. Top: with 60 SDS molecules, Bottom: with 90 SDS molecules. The $g_{\mathrm{S}-\mathrm{Al}}(r)$ is calculated for the aluminum $\left[\mathrm{Al}_{2}\left(\mathrm{SO}_{4}\right)_{3}\right]$ and Sulfur (SDS) pairs.
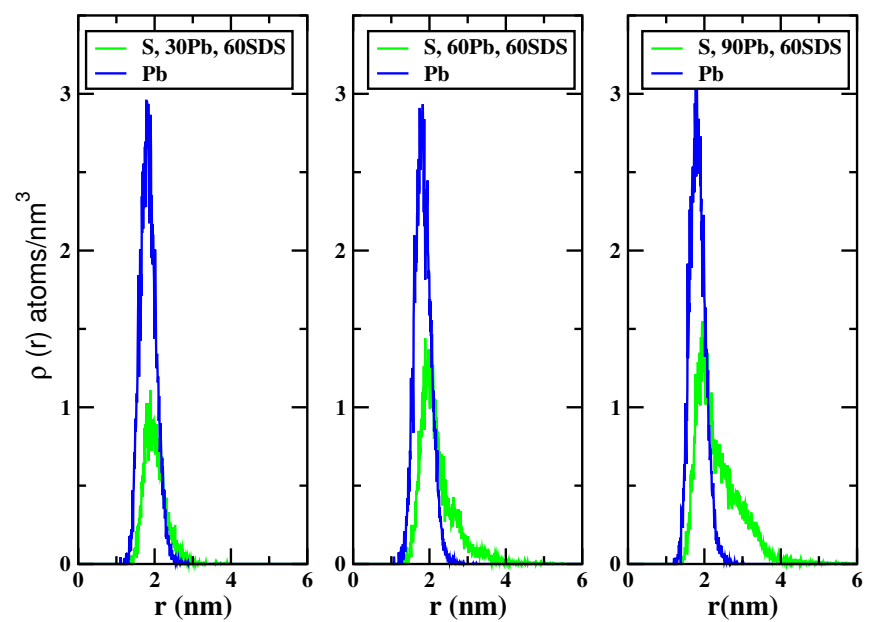

Figure 3. (Colour online) Radial density profiles for sulfur (SDS) and lead $\left(\mathrm{PbSO}_{4}\right)$ at different salt concentrations, i.e., the number of $\mathrm{Pb}$ ions, for a micelle of 60 SDS.

ions show a first high peak close to the SDS peak, suggesting a few number of metal ions approaching and adsorbed by the SDS micelle, in particular to the headgroups. In the same plots there is also noted a shoulder and even a tail in the ion profiles indicating that few metals are away from the micelle, i.e., they are not held by the SDS aggregate.

The number of ions attached on the micelle surface was calculated by integration of the number density

$$
N_{a d}=\int_{0}^{R_{c}+r_{c}} 4 \pi r^{2} \rho(r) \mathrm{d} r .
$$



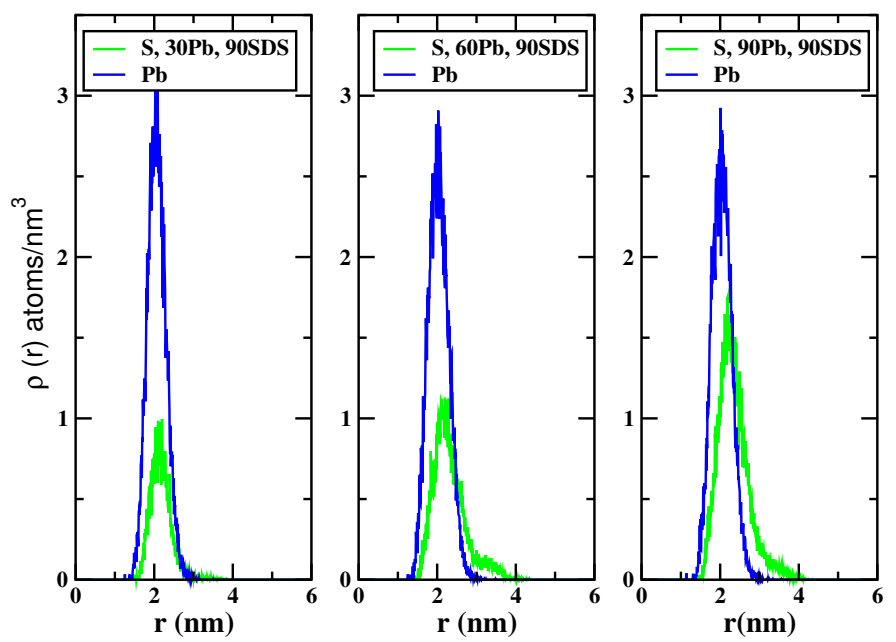

Figure 4. (Colour online) Radial density profiles for sulfur (SDS) and lead $\left(\mathrm{PbSO}_{4}\right)$ at different salt concentrations, i.e., the number of $\mathrm{Pb}$ ions, for a micelle of $90 \mathrm{SDS}$.

The integration was performed in radial shells from the center of the micelle up to the upper limit defined by $R_{c}+r_{c}$, where $R_{c}$ is the position of the SDS headgroups peak in the density profile (see figures 3 and 4 and $r_{c}$ is obtained by the position of the first minimum in the radial distribution function of the sulfur $(\mathrm{S})$ with lead $(\mathrm{Pb})$ [or aluminum $(\mathrm{Al})$ ] ions, i.e., the position of the first nearest neighbors of the metal ions with the S-atoms since at this distance it is considered that the ions are retained by the SDS micelle. In fact, the position of the sulfur peaks of the density profiles can give us information on the radius of the micelle, around $2 \mathrm{~nm}$, in agreement with our previous data and with the values of earlier simulations and experiments reported in the literature [28].
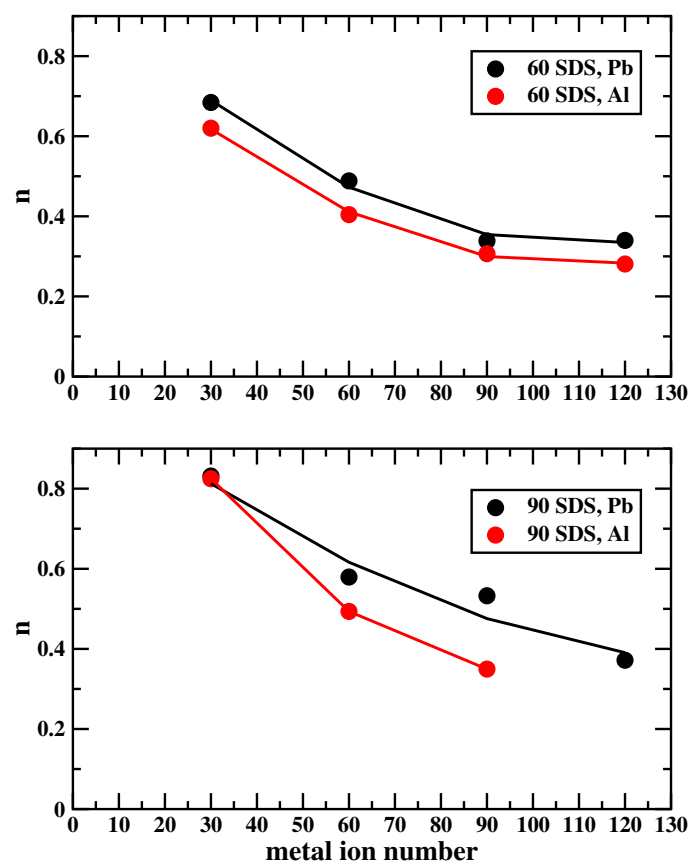

Figure 5. (Colour online) Retention ratio of metal ions $(\mathrm{Pb}$ or $\mathrm{Al})$ at different salt concentrations in both micelle, 60 (top) and 90 (bottom) SDS. Solid lines are only to guide. 

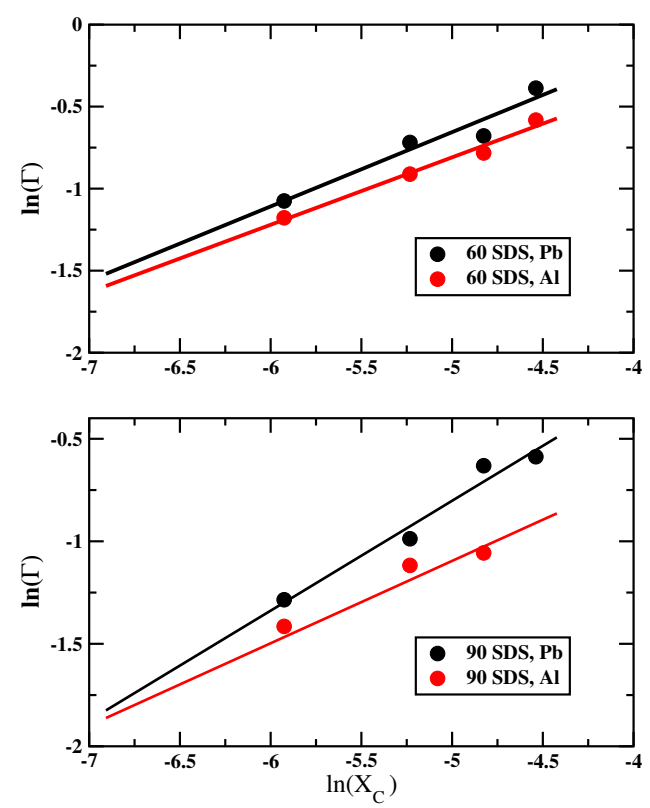

Figure 6. (Colour online) Adsorption isotherms of metal ions ( $\mathrm{Pb}$ or $\mathrm{Al}$ ) on SDS micelles at different salt concentrations. Top: micelle with 60 SDS molecules, bottom: micelle with 90 SDS molecules.

Then, the amount of metallic ions retained by the SDS micelles was estimated with the ratio $n=$ $\left(N_{a d} / N_{T}\right)$ calculated with the number of metal ions adsorbed on the SDS micelles divided by their total number $\left(N_{T}\right)$. The above procedure was conducted and analyzed at different time steps throughout the entire simulation and it was observed that after $30 \mathrm{~ns}$, the number of ion retained did not change significantly. Therefore, the results were taken up to $50 \mathrm{~ns}$, when plots reached a plateau in time.

In figure 5, the percentage of $\mathrm{Al}$ or $\mathrm{Pb}$ ions retained by the different SDS micelles are showed. As a general trend, the ion retention decreases as the salt concentration increases. It is also observed that the big micelle retains more metallic ions than the small one regardless the salt concentration. In fact, it is noted that the SDS micelles work better to capture $\mathrm{Pb}$ ions than to capture $\mathrm{Al}$ ions, i.e., micelles adsorb more lead than aluminum at the same salt concentration.

\subsection{Adsorption isotherms}

The study can also be analyzed in terms of ion adsorption isotherms on the SDS micelle surface. Then, adsorption was calculated as the amount of ions attached to the micelle normalized with the number of SDS molecules, i.e.,

$$
\Gamma=\frac{N_{a d}}{N_{\text {SDS }}}
$$

where $N_{a d}$ is the number of metal ions retained on the micelle and $N_{\mathrm{SDS}}$ is the total number of SDS molecules in the system, i.e., the relation between the adsorbate adsorbed and the adsorbent. In figure 6 adsorption isotherms are plotted, in a log-log plot, as a function of the ion concentration, $X_{c}$,

$$
X_{c}=\frac{N_{\text {ion }}}{N_{\text {water }}},
$$

where $N_{\text {ion }}$ and $N_{\text {water }}$ are the total number of metal ions and the total number of water molecules in the system, respectively. The adsorption data of figure 6 can be fitted with a straight line

$$
\ln (\Gamma)=m \ln \left(X_{c}\right)+\ln (K),
$$


where the slope, $m$, and the intercept of the line, $\ln (K)$, can be related to the constants of the Freundlich isotherm [30]

$$
\Gamma=K X_{c}^{1 / n} .
$$

$X_{c}$ is the concentration, $K$ is a constant related with the adsorption capacity and $1 / n(=m)$ is the saturation rate of adsorption. In table 1, the values of $K$ and $n$ for the different systems are given. It is observed that $K$ is higher for the systems with $\mathrm{Pb}$ ions regardless of the size of the micelle, i.e., micelles with $\mathrm{Pb}$ salts have a higher capacity of adsorption than micelles with $\mathrm{Al}$ salts.

Table 1. Adsorption $K$ and $n$ constants.

\begin{tabular}{|c|c|c|}
\hline 60 SDS & $K$ & $n$ \\
\hline $\mathrm{Pb}$ & 4.99 & 2.21 \\
$\mathrm{Al}$ & 3.47 & 2.43 \\
\hline 90 SDS & $K$ & $n$ \\
\hline $\mathrm{Pb}$ & 6.53 & 1.87 \\
$\mathrm{Al}$ & 2.49 & 2.50 \\
\hline
\end{tabular}

\section{Conclusions}

The adsorption of lead and aluminum ions from aqueous solutions using micelles of sodium dodecyl sulfate (SDS) surfactants, was investigated. The studies were carried out using $\mathrm{PbSO}_{4}$ and $\mathrm{Al}_{2}\left(\mathrm{SO}_{4}\right)_{3}$ salts at different concentrations and sizes of the SDS micelles. From the density profiles it is observed that the negative SDS headgroups are close to the positive metallic ions, and since those SDS headgroups are located on the exterior of the micelle it can be assumed that ions are trapped on the surface. The partial pair distribution functions show a higher probability to find metallic ions close to the SDS headgroups in the big micelle than in the small one. The results also show that SDS micelles are more efficient to retain $\mathrm{Pb}$ than $\mathrm{Al}$ ions regardless of the aggregate size. In fact, as a general trend, a big micelle promotes more adsorption of metal ions than a small one, i.e., since big micelles have larger surfaces than small ones there is a high probability to hold metal ions in those systems. Moreover, the results also show that low salt concentrations work better to hold ions on the surfactant surface. The present work can be used to study the retention of contaminant particles in aqueous solutions, i.e., it shows how surfactant micelles can help trap the metal pollutant ions in water and is complementary to the previous investigation where SDS micelles were also used to study the retention of lead and mercury ions [18]. It is worth mentioning that the results are given for a particular combination rule between unlike atoms. With these parameters, simulations of metallic ions-water [21] and SDS-water [19] have been tested in the literature with good results. However, to the best of our knowledge, there are no reported works on metallic ions and SDS surfactants. Different cross-interactions could give different data, the quantitative results may change, though we think that the qualitative results may not change, i.e., the phenomenon will show the same trends. Finally, from the present work and earlier results [18] we conclude that the counterion, in this case $\mathrm{SO}_{4}$ or $\mathrm{NO}_{3}$, influences the ion retention. In fact, current data comparisons with those of reference [18] show that the capture of $\mathrm{Pb}$ ions is better in $\mathrm{PbSO}_{4}$ salts than in $\mathrm{Pb}\left(\mathrm{NO}_{3}\right)_{2}$ salts.

\section{Acknowledgements}

This work was supported by DGAPA-UNAM-Mexico grant IN105120, Conacyt-Mexico grant A1S-29587 and DGTIC-UNAM LANCAD-UNAM-DGTIC-238 for supercomputer facilities. We also acknowledge Alberto Lopez-Vivas, Cain Gonzales-Sanchez and Alejandro-Pompa for technical support in the computer calculations. 


\section{References}

1. Wang H., Zhou A., Peng F., Yu H., Yang J., J. Colloid Interface Sci., 2007, 316, 277, doi $10.1016 /$ j.jcis.2007.07.075

2. Deng L. P., Su Y. Y., Su H., Wang X. T., Zhu X. B., J. Hazard. Mater., 2007, 143, 220, doi $10.1016 /$ j.jhazmat.2006.09.009

3. Wang J., Feng X., Andersen C. W. N., Xing Y., Shang 1., J. Hazard. Mater., 2012, 221, 1, doi $10.1016 /$ j.jhazmat.2012.04.035

4. Nanseu-Njiki C. P., Tchamango S. R., Ngom P. C., Darchen A., Ngameni E., J. Hazard. Mater., 2009, 168, 1430, doi:10.1016/j.jhazmat.2009.03.042.

5. Ku Y., Jung I. L., Water Res., 2001, 35, 135, doi 10.1016/S0043-1354(00)00098-1

6. Alyuz B., Veli S., J. Hazard. Mater., 2009, 167, 482, doi $10.1016 /$ j.jhazmat.2009.01.006

7. Yanagisawa H., Matsumoto Y., Machida M., Appl. Surf. Sci., 2010, 256, 1619, doi:10.1016/j.apsusc.2009.10.010

8. Landaburu-Aguirre J., García V., Pongrácz E., Keiski R. L., Desalination, 2009, 240, 262, doi $10.1016 /$ j.desal.2007.11.077

9. Dermont G., Bergeron M., Mercier G., Richer-Lafleche M., J. Hazard. Mater., 2008, 152, 1, doi $10.1016 /$ j.jhazmat.2007.10.043

10. Anbia M., Amirmahmoodi S., Arabian J. Chem., 2016, 9, S319, doi 10.1016/j.arabjc.2011.04.004

11. Huang C. P., Blankenship D. W., Water Res., 1984, 18, 37, doi 10.1016/0043-1354(84)90045-9

12. Hu X., Li Y., Sun H., Song X., Li Q., Cao X., Li Z., J. Phys. Chem. B, 2010, 114, 8910, doi 10.1021/jp101943m

13. Liu Q., Yuan S., Yan H., Zhao X., J. Phys. Chem. B, 2012, 116, 2867, doi $10.1021 /$ jp2118482

14. Peredo-Mancilla D., Domimguez H., J. Mol. Graphics Modell., 2016, 65, 108, doi 10.1016/j.jmgm.2016.02.011

15. Salazar-Arriaga A. B., Domimguez H., Chem. Phys., 2020, 539, 110945, doi $10.1016 /$ j.chemphys.2020.110945

16. Valencia-Ortega M., Fuentes-Azcatl R., Dominguez H., J. Mol. Graphics Modell., 2019, 92, 243, doi $10.1016 /$ j.jmgm.2019.08.003.

17. Espinosa-Jimenez H., Dominguez H., Rev. Mex. Fis., 2019, 65, 20.

18. Cedillo-Cruz E., Garcia-Ramos D., Dominguez H., Chem. Phys. Lett., 2021, 767, 138340, doi $10.1016 /$ j.cplett.2021.138340.

19. Rios-Lopez M., Mendez-Bermudez J. G., Dominguez H., J. Phys. Chem. B, 2018, 122, 4558, doi $10.1021 /$ acs.jpcb.8b01452.

20. Pacheco-Blas M. del A., Dominguez H., Rivera M., Chem. Phys., 2017, 485, 13, doi $10.1016 /$ j.chemphys.2017.01.002

21. Heinz H., Vaia R. A., Farmer B. L., Naik R. R., J. Phys. Chem. C, 2008, 112, 17281, doi: 10.1021/jp801931d

22. Berendsen H. J. C., Grigera J. R., Straatsma T. P., J. Phys. Chem., 1987, 91, 6269, doi 10.1021/j100308a038

23. Hess B., Kutzner C., van der Spoel D., Lindahl E., J. Chem. Theory Comput., 2008, 4, 435, doi $10.1021 / \mathrm{ct} 700301 \mathrm{q}$

24. Hoover W. G., Phys. Rev. A, 1985, 31, 1695, doi:10.1103/PhysRevA.31.1695.

25. Parrinello M., Rahman A., J. Appl. Phys., 1981, 52, 7182, doi $10.1063 / 1.328693$

26. Essmann U., Perera P., Berkowitz M. L., Darden T., Lee H., Pedersen L. G., J. Chem. Phys., 1995, 103, 8577, doi $10.1063 / 1.470117$

27. Hess B., Bekker H., Berendsen H. J. C., Fraaije J. G. E. M., J. Comput. Chem., 1997, 18, 1463 , doi 10.1002/(SICI)1096-987X(199709)18:12<1463::AID-JCC4>3.0.CO;2-H

28. Bruce C. D., Berkowitz M. L., Perera L., Forbes M. D. E., J. Phys. Chem. B, 2002, 106, 3788, doi $10.1021 / \mathrm{jp} 013616 \mathrm{z}$

29. Almgrem M., Swarup S., J. Phys. Chem., 1982, 86, 4212, doi $10.1021 /$ j100218a024

30. Freundlich H., Kapillarchemie: eine Darstellung der Chemie der Kolloide und verwandter Gebiete, Akademische Verlagsgesellschaf, Leipzig, 1909. 


\title{
Адсорбція іонів металів з водних розчинів на агрегатах поверхнево-активних речовин: дослідження методом молекулярної динаміки
}

\author{
Е. Г. Чавес-Мартінес, Е. Седільо-Крус, Е. Домінгес
}

Інститут матеріалознавства, Національний незалежний університет Мехіко, 04510, Мехіко, Мексика

На основі методу молекулярної динаміки досліджується адсорбція іонів металів на агрегатах поверхневоактивних речовин. 3 використанням іонних солей, таких як сульфат свинцю $\left(\mathrm{PbSO}_{4}\right)$ і сульфат алюмінію $\left[\mathrm{Al}_{2}\left(\mathrm{SO}_{4}\right)_{3}\right]$, досліджено адсорбцію свинцю та алюмінію для різних концентрацій солі та різних розмірів агрегатів поверхнево-активної речовини (міцел). Міцели будувалися у вигляді сфер, утворених аніонною поверхнево-активною речовиною - додецилсульфатом натрію (SDS). Електростатичні взаємодії між позитивними іонами і від'ємно зарядженими групами SDS сприяють захопленню частинок металу поверхнею агрегата. Адсорбцію металів досліджено на основі аналізу профілів радіальної густини, парціальної парної функції розподілу та ізотерм адсорбції. Показано, що міцели SDS краще адсорбують іони свинцю, ніж алюмінію, незалежно від розміру агрегатів чи концентрації солі.

Ключові слова: адсорбція іонів металів, аніонна поверхнево-активна речовина, поверхнева адсорбція, молекулярна динаміка, іонні солі 


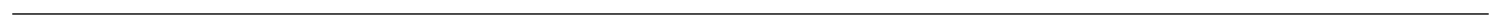

